\title{
Sodium iodide symporter (NIS) in extrathyroidal malignancies: focus on breast and urological cancer
}

\author{
Salvatore Micali ${ }^{1}$, Stefania Bulotta ${ }^{2}$, Cinzia Puppin ${ }^{3}$, Angelo Territo ${ }^{1 *}$, Michele Navarra $^{4}$, Giampaolo Bianchi ${ }^{1}$, \\ Giuseppe Damante ${ }^{3}$, Sebastiano Filetti ${ }^{5}$ and Diego Russo ${ }^{2}$
}

\begin{abstract}
Background: Expression and function of sodium iodide symporter (NIS) is requisite for efficient iodide transport in thyrocytes, and its presence in cancer cells allows the use of radioiodine as a diagnostic and therapeutic tool in thyroid neoplasia. Discovery of NIS expression in extrathyroidal tissues, including transformed cells, has opened a novel field of research regarding NIS-expressing extrathyroidal neoplasia. Indeed, expression of NIS may be used as a biomarker for diagnostic, prognostic, and therapeutic purposes. Moreover, stimulation of endogenous NIS expression may permit the radioiodine treatment of extrathyroidal lesions by concentrating this radioisotope.
\end{abstract}

Results: This review describes recent findings in NIS research in extrathyroidal malignancies, focusing on breast and urological cancer, emphasizing the most relevant developments that may have clinical impact.

Conclusions: Given the recent progress in the study of NIS regulation as molecular basis for new therapeutic approaches in extrathyroidal cancers, particular attention is given to studies regarding the relationship between NIS and clinical-pathological aspects of the tumors and the regulation of NIS expression in the experimental models.

Keywords: Sodium iodide symporter (NIS), Extrathyroidal tissues, Breast cancer, Urological malignancies, Gene therapy

\section{Introduction}

The sodium iodide symporter (NIS) is a glycosylated protein with 13 trans-membrane domains, belonging to the solute carrier family [1,2] (Figure 1). It is able to transport $2 \mathrm{Na}^{+}$and one $\mathrm{I}^{-}$through the membranes, depending on the $\mathrm{Na}^{+}$gradient maintained by $\mathrm{Na}^{+} / \mathrm{K}^{+}$ATPase [3]. The highest expression levels are detectable in the thyroid, where is located in the basolateral membrane of the thyrocytes [3]. NIS activity is necessary to provide the iodide concentration gradient inside thyroid cells, used for the synthesis of thyroid hormones in a multistep process requiring the action of pendrin, thyroid peroxidase (TPO), dual oxidase-2, and thyroglobulin. The thyroid stimulating hormone (TSH) is the main regulator of the iodide transport in the thyrocytes, and it does so by acting on NIS

\footnotetext{
* Correspondence: territoangelo@tiscali.it

${ }^{1}$ Department of Urology, University of Modena and Reggio Emilia, Via Largo del Pozzo, 71, Modena 41100, Italy

Full list of author information is available at the end of the article
}

transcription, NIS protein half-life, and its translocation to the thyrocyte basal plasma membranes [3-5].

\section{NIS expression in thyroid cancer and radioiodide therapy}

The presence of NIS in thyroid cancer cells, by allowing highly efficient iodide accumulation, is exploited for the use of radioactive substrates of NIS for diagnostic and therapeutic purposes. Thus, when functional NIS expression is maintained in metastatic lesions, radioiodide-131 $\left({ }^{131} \mathrm{I}\right)$ administered after total thyroidectomy permits selective ablation of neoplastic tissue. However, expression of endogenous NIS and subsequent radioiodide uptake is often reduced in thyroid cancer, especially in metastatic tissue [6]. Stimulation of NIS expression is therefore required prior to ${ }^{131} \mathrm{I}$ administration, and is currently obtained by elevating TSH levels $[7,8]$. However, there are some tumors, especially the less differentiated ones, that are unresponsive to such a treatment $[7,8]$. An increase of NIS expression, and subsequent iodide concentration 


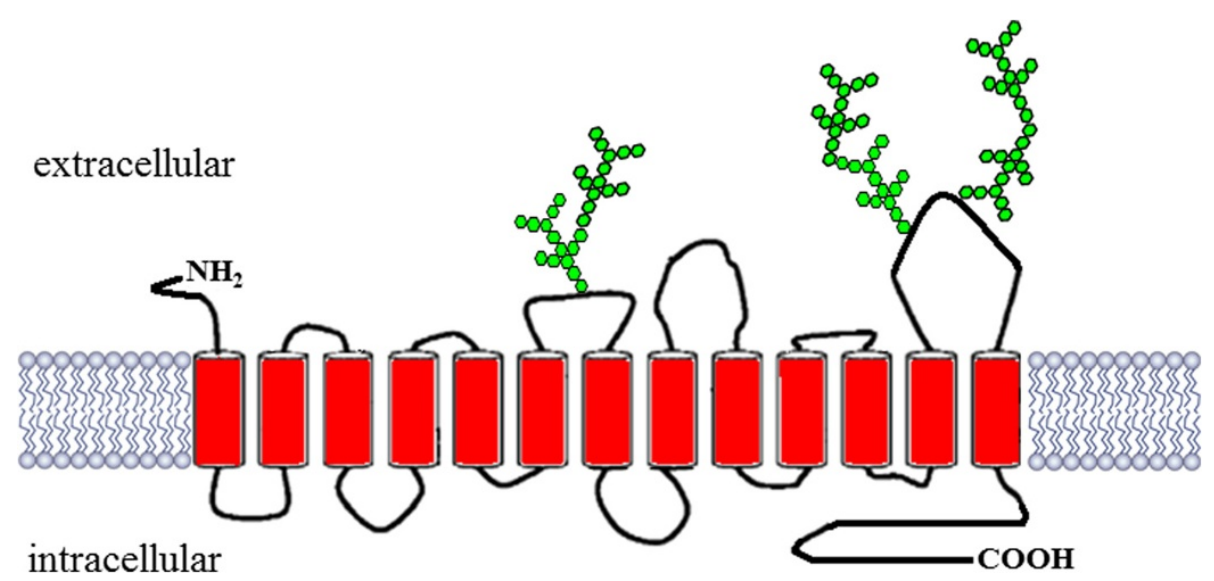

Figure 1 NIS schematic model. The transporter contains 13 transmembrane domain (in red) and 3 N-linked glycosylation sequences (in green).

ability, has been successfully obtained in thyroid tumor cells also by using inhibitors of some oncogenic signaling pathways in in vivo and in vitro experimental models [9]. Indeed, restoration of NIS expression by differentiationinducible agents, acting by genetic or epigenetic mechanisms $[9,10]$, or enhancement of iodide uptake by using potential NIS translocation stimulators, have been reported in less differentiated thyroid cancer cells [11]. Altogether, such findings provide a promising basis to extend the radioiodine approach for those tumors that are still nonresponsive to radioiodine treatment.

\section{NIS expression in extrathyroidal tissues}

Various extra-thyroidal tissues express NIS at mRNA and/or protein levels [12]. By using immunohistochemistry, Wapnir and coworkers showed that several normal tissues, including bladder, colon, endometrium, kidney, prostate, and pancreas, expressed NIS protein. However, plasma membrane immunopositivity was confirmed only in salivary ductal, gastric mucosa, and lactating mammary cells [13] (Table 1). Iodide uptake was also reported in choroid plexus cells in a pre-NIS era [14-16].

\section{Table 1 NIS expression in normal extrathyroidal tissues}

\begin{tabular}{lccc}
\hline Tissues & mRNA & Protein $\left(^{*}\right)$ & References \\
\hline Lacrimal glands & & + & {$[17]$} \\
Salivary glands & + & + & {$[13,18-20]$} \\
Stomach & & + & {$[13,18,19]$} \\
Colon & + & + & {$[13]$} \\
Testis & & + & {$[21]$} \\
Endometrium & + & + & {$[13]$} \\
Placenta & & + & {$[22]$} \\
Lactating mammary & & $+13,23]$ \\
\hline
\end{tabular}

(*) only when detected in the plasma membrane.
NIS acts in salivary glands, stomach, and intestine to provide efficient adsorption of iodide contained in the food [3]. While salivary glands (mainly the parotid glands) and stomach cells transfer iodide from the bloodstream to the lumen of the gastrointestinal tract [24], intestines take the iodide from the lumen to transport it into circulation [25]. For this reason NIS is expressed on the basolateral membrane of salivary ductal and gastric mucosa cells $[19,26]$, and, viceversa, on the apical membrane of the brush border of small intestine [25].

Lactating mammary glands are able to provide a sufficient amount of iodide in the milk to reach a concentration of approximately $150 \mu \mathrm{g} / \mathrm{L}$ [27]. This is obtained thanks to abundant NIS expression on the basolateral membrane of the alveolar cells [28], which mediates the transfer from the bloodstream into milk. Stimulation of NIS expression occurs during lactation due to increased levels of various hormones, including oxytocin, prolactin, and estrogens $[23,28]$. In contrast, non-lactating normal breast tissue does not express NIS protein and is not able to accumulate iodine, unless pathological conditions like hyperprolactinoemia occur [29]. Indeed, Bruno and coworkers [12], investigating a series of patients who underwent whole-body ${ }^{131}$ I following the administration of high doses of ${ }^{131}$ I for thyroid carcinoma, demonstrated that only a very small fraction of normal breast tissues presented efficient iodine uptake.

NIS also operates in placental cells, contributing to the transfer of iodide from the mother to the fetal circulation [22].

Finally, the presence of NIS mRNA and protein was demonstrated at low levels also in fetal and adult human testicular tissues [21]. Expression of NIS in the germinal cells may represent the molecular basis for the concentration of radioiodine, responsible for the alterations observed in male patients undergoing this treatment for thyroid cancer. However, the low amount of NIS in the plasma membranes, as well as the presumable rapid 
efflux of radioiodide due to the absence of an organification machinery in testicular cells, may explain the presence of only transient alterations observed in these patients [21].

\section{NIS expression and radioiodide uptake in extrathyroidal tumors}

The crucial role of radioiodide-based therapy in thyroid cancer and the characterization of the molecular basis of iodide transport following the cloning of NIS, including its detection in some extrathyroidal tissues, has encouraged a large series of studies aimed to try to extend radioiodine treatment even to extrathyroidal tumors after induction of NIS expression.

When this strategy is adopted for the treatment of extrathyroidal tumors, it becomes necessary to prevent radioiodide uptake and concentration in normal thyrocytes. Selective downregulation of NIS expression, as well inhibition of organification, has been successfully obtained by using combination of $\mathrm{T} 3$ and methimazole [30]. In addition, also high doses of iodide are able to downregulate NIS expression in normal thyrocytes.

The two strategies currently explored to induce NIS expression in cancer cells include the transfer of NIS gene using vectors (mainly viruses) and constructs able to ensure the selective expression in tumor cells, or, alternatively, the stimulation of the expression of a functional endogenous NIS.

In the next sections, we will describe recent findings regarding NIS expression in extrathyroidal malignancies, focusing on breast and urological cancers, and emphasizing the most relevant developments in both gene therapy and endogenous NIS stimulation strategies.

\section{NIS and breast cancer}

\section{NIS expression in breast cancer}

The demonstration of NIS presence in lactating breast [23] has suggested that this protein could be expressed also in breast cancer (BC). Accordingly, in the seminal study in which NIS expression in lactating breast was discovered, it was shown that this protein is expressed in more than $80 \%$ of both invasive and in situ BCs [23]. However, both plasma membrane and intracellular immunohistochemical signal was detected (Table 2), which is in contrast to the only basolateral membrane signal detected in lactating breast. The notion that the NIS protein is expressed in a large number of breast carcinomas was confirmed by the same group by investigating a larger cohort of samples [13]. In this study it was found that NIS is also expressed in about $80 \%$ of fibroadenomas. Again, in breast carcinomas, the NIS protein was predominantly located in the cytoplasm, suggesting that in $\mathrm{BC}$ a deficiency of NIS trafficking from cytoplasm to plasma membrane occurs. High levels of NIS positivity in $\mathrm{BC}$ by immunostaining has also been described in other studies $[31,32]$. It should be pointed out, however,
Table 2 NIS expression in breast cancer tissues

\begin{tabular}{lccc}
\hline No of specimens & mRNA & Protein positive (\%) & References \\
\hline 45 & n.d. & 69 & {$[23]$} \\
50 & n.d. & 90 & {$[31]$} \\
12 & + & 100 & {$[35]$} \\
27 & n.d. & 30 & {$[30]$} \\
23 & n.d. & 65 & {$[36]$} \\
28 & + & 7 & {$[34]$} \\
75 & + & n.d. & {$[37]$} \\
32 & n.d. & 92 & {$[32]$} \\
\hline
\end{tabular}

n.d.: not determined.

that such a large positivity, when obtained by immunohistochemistry in the cytoplasmic compartment, could be due to non-specific staining [33]. In order to understand the molecular basis of NIS inability to target the plasma membrane in a large fraction of $\mathrm{BC}$, genes whose expression is associated to NIS plasma membrane localization have been recently identified by microarray analysis [34]. Interestingly, the cysteinyl-tRNA synthetase gene is highly associated with cell surface NIS protein levels only in the estrogen receptor (ER)-positive BC subtype, suggesting that molecular mechanisms responsible for reduced plasma membrane localization of NIS may be different in a distinct subtype of BC [34].

Triple-negative BCs (TNBCs) are defined by the absence of ER, the progesterone receptor (PR), and the human epidermal growth factor receptor 2 (HER2) expression [38]. Because of absence of ER, PR, and HER2, TNBC cannot be treated by hormonal therapy or HER2-targeting compounds, leaving chemotherapy as the only therapeutic tool. Patients with this disease have a worse outcome than patients with other BC subtypes $[38,39]$. It has been shown that NIS is expressed in about $65 \%$ of TNBCs and that in a fraction of them a strong plasma membrane localization is present [40]. Accordingly, in the same study, efficient iodine uptake was detected by ${ }^{123}$ I scintigraphy in a patient. The notion that the NIS protein expressed in BC is able to allow radioiodine uptake has been reported in other studies as well. In fact, by studying women with infiltrating duct carcinoma, high NIS expression at both transcriptional and translational level and its ability to transport iodine in cancer tissue has been demonstrated [35]. Recently, Damle and coworkers reported that the radioiodine uptake in breast cancer specimens was significantly higher as compared to that observed in the normal tissue from the same patients [41]. In this study, $50 \%$ of breast cancer samples were positive for radioiodine uptake as well as NIS gene expression [41].

Expression and function of NIS has been investigated also in metastatic BC. Wapnir and coworkers investigated 23 patients with metastasis predominantly at the level of lung, liver, bone, and lymph node/soft tissues [30]. Eight 
of these subjects showed protein NIS expression, and iodide uptake was noted in two of eight NIS-expressing tumors. The same group has more recently investigated NIS expression in brain metastasis by immunohistochemistry [40]. In $75 \%$ of cases a predominant cytoplasmic signal was detected; however, plasma membrane immunoreactivity was detected only in $23.8 \%$ of NIS-positive samples. Altogether these data would indicate that NIS protein is correctly located and is able to accumulate iodine only in a small fraction of $\mathrm{BC}$ metastasis.

Besides immunohistochemical studies, high expression of NIS mRNA has been shown by quantitative reverse transcriptase polymerase chain reaction (RT-PCR) evaluation. Oh and coworkers have shown that NIS gene expression was present in approximately one-third of BC tissues, and no relationship was found between NIS mRNA levels and hormonal receptors expression [42]. More recently, Ryan et al. confirmed that NIS expression levels are significantly higher in $\mathrm{BC}$ and fibroadenoma than in normal tissue, with the highest levels of NIS mRNA observed in fibroadenoma tissues [37]. At present, detection of NIS expression levels has no prognostic value: in fact no significant relationship has been detected between NIS mRNA levels and clinical characteristics of the tumors [37]. In addition, immunohistochemistry of a subset of tumor tissues in the same cohort confirmed the presence of NIS protein both in selected malignant carcinomas and benign fibroadenomas [37].

\section{NIS-based gene therapy}

A strategy attempted to achieve significant radioiodine uptake by the BC cells is using gene therapy to introduce an "active" exogenous NIS gene. Montiel-Equihua and coworkers have generated a replication-incompetent adenovirus, AdSERE, in which the expression of NIS is directed by an estrogen-responsive promoter [43]. Therefore, this vector would be active only in ER-positive BC (about $60 \%$ of all BC). In vitro, AdSERE mediated human NIS expression and iodide uptake in ER+ cell lines (MCF7 and ZR75-1). Moreover, the authors show that ZR75-1 AdSERE-positive xenografts in nude mice can be imaged after ${ }^{99 \mathrm{~m}} \mathrm{Tc}$ injection and their growth suppressed with therapeutic doses of ${ }^{131}$ I [43]. The use of a non-replicative adenovirus has been recently reported by the Santisteban group [44]. In this virus, NIS transcription is driven by promoters of human telomerase subunits RNA (hTR) and human telomerase reverse transcriptase (hTERT). Telomerase is a ribonucleoprotein that is essential in most human cancers but is not expressed in most normal tissues [45-47]. Thus, hTR and hTERT promoters would be active only in cancer cells. When the BC cell line MDAMB-231 was infected by this virus, expression of NIS protein, iodine uptake, as well as reduced cell survival after radioiodine administration was observed. A conditionally replicating adenovirus (CRAd) in which the E1a gene is driven by the tumor-specific promoter Mucin 1 (MUC-1) has also been generated [48]. This virus can efficiently replicate only in MUC-1 overexpressing cells, including BC cells [49]. In addition, this virus contains the transcriptional cassette RSV promoter-hNIScDNAbGH polyA in the E3 region, which permits NIS to express at high levels. After infection of the MUC-1-positive BC cell line T47D, virus replication, cytolysis, and release of infective viral particles, as well as iodide uptake, were observed [48].

The increase of the exogenous, virus-mediated expression of the NIS gene by pharmacological treatment has been also investigated. Treatment with retinoic acid (RA) has been shown to increase NIS expression in MCF7 cells infected by a non-replicating adenovirus in which NIS expression is controlled by the potent cytomegalovirus (CMV) promoter [50]. Indeed, the CMV promoter contains an RAresponsive element [51]. A large increase of iodine uptake has been also described in virus-infected, RA-treated MCF7 cells.

\section{Induction of endogenous NIS}

Though NIS expression has been demonstrated in most BCs, only in very few patients would spontaneous NIS expression allow efficient radioiodine uptake. For this reason, a large body of investigation has been undertaken to identify compounds that are able to increase NIS expression, its localization in plasma membrane, and iodine uptake. The major inductor of NIS expression in breast cancer cells is certainly RA. Several compounds of the RA family stimulate NIS expression, including all-trans RA, 13-cis RA, and AGN190168, all of which are already used for medical purposes [9]. Among them, the one used most to activate NIS expression in BC cells is all-trans RA. NIS expression has been induced in several BC cell lines including MCF7, T47D, and BT474 [52]. Several data indicate that RA induces NIS expression primarily by activating $\mathrm{RAR} \beta / \mathrm{RXR} \alpha$ heterodimer receptors. Hormonebound receptor may act through two mechanisms. The first is binding to an element located in cis to the NIS gene [9]. It has been demonstrated that in MCF7 cells, treatment by RA induce retinoic acid receptor-alpha (RAR $\alpha$ ) binding to a retinoic acid response element located in intron 2 of the NIS gene [53]. It must be mentioned, however, that the NIS regulation by RAR $\alpha$ was not confirmed in a different study performed on MCF7 cells [9]. The second mechanism is activation of the phosphoinositide 3kinase (PI3K) pathway and the p38MAPK pathway. In MCF7 cells, Ohashi and coworkers have shown that either treating cells with the PI3K inhibitor LY294002 or inducing knockdown of p85alpha (a regulatory subunit of PI3K) decreases RA-induced NIS expression. Moreover, the AKT inhibitor VIII decreases iodine uptake in MCF7 cells in a dose-dependent manner [54]. Kogai and coworkers, by 
using both gain and loss of function experiments, have shown that $\mathrm{p} 38 \beta$ plays a role in the RA-induced NIS expression increase in MCF7 cells [55]. Interestingly, in the same study it was shown that in FRTL5 thyroid cells not the $\beta$ but the p38 $\alpha$ isoform has a role in NIS control of expression. Moreover, NIS induction was also observed in mouse MCF7 xenograft [56,57], although this finding was not confirmed by another group [58]. These different results using MCF7 cells might be due to heterogeneity of this cell line [59].

In addition to gene expression, the PI3K pathway regulates NIS localization. Glycosylation of NIS protein is necessary to plasma membrane localization [60]. In MCF7 cells, overexpression of PI3K increases the non-glycosylated NIS protein [61]. In the same study, it was shown that the presence of NIS in the plasma membrane as well as iodine uptake was reduced by an active mutant of PI3K. It appears, therefore, that activation of the PI3K signaling pathways exerts opposite effects on NIS: expression is activated while NIS localization in the plasma membrane is inhibited.

Several compounds cooperate with RA in inducing NIS expression in $\mathrm{BC}$ cell lines. RA-induced enhancement of NIS is increased by hydrocortisone, dexamethasone, troglitazone (a peroxisome proliferator-activated receptor $\gamma$, PPAR $\gamma$, agonist), histone deacetylase (HDAC) inhibitors (tricostatin A and sodium butyrate), and carbamazepine [58,62-64]. Hydrocortisone, dexamethasone, troglitazone, and carbamazepine cooperate with RA also in inducing iodine uptake. Interestingly, by using MCF7 xenografts in nude mice, it has been shown that RA alone is not able to increase iodine uptake; however, significant increase in ${ }^{123} \mathrm{I}$ accumulation occurs when RA is used in combination with dexamethasone [65]. Other stimulators, such as prolactin, insulin, and insulin growth factor (IGF)-I and II, are able to increase NIS mRNA levels in MCF7 cells also in the absence of RA [66]. Fortunati and coworkers reported that the HDAC inhibitor LBH589 significantly induced NIS mRNA and protein levels as well as iodine uptake in several BC cell lines [67]. Table 3 summarizes the data regarding the stimulation of iodide uptake in breast cancer cells.

\section{NIS and urological malignancies \\ NIS expression in prostate cancer}

In 2010 Navarra et al. analyzed the expression of NIS in tissue specimens from a large series of patients with prostate adenocarcinoma [70]. They demonstrate that approximately half of prostate cancers express the NIS at both mRNA and protein levels (Table 4). In addition, NIS expression correlates with aggressive features of the tumors such as Gleason score and pathologic stage, thus suggesting the hypothesis that these changes are a result of the dedifferentiation process occurring during a late stage of malignant transformation. A quantitative evaluation of NIS protein levels, using more sensitive methods than immunohistochemistry, will provide more details on the role of NIS as biomarker for prostate cancer aggressiveness, as reported for beta-catenin using fluorescence microscopy [71]. In prostate tumor cells expressing NIS, it appears primarily in the cytosolic fraction of the acini as a result of an incomplete maturation or too low levels of expression, as hypothesized in some thyroid and breast cancers $[72,73]$. In any case, the observed strong staining of the cytoplasm makes it difficult to discern plasma membrane immunoreactivity, so that the presence of a functional NIS in the tumor cell plasma membranes could not be proved.

A recent report, proposing the function of cytoplasmic NIS as an element of a pathway involved in tumor cell invasive capacity [76], suggests a role of cytoplasmic NIS in tumor aggressiveness, strengthening the hypothesis of using NIS expression as biomarker for defining individuals with biologically active prostate cancer.

\section{NIS expression in testicular cancer}

In 2003 Wapnir et al., by analyzing a few specimens of testicular tumors by immunohistochemistry, first evidenced the expression of NIS in some cores of these tumors [13]. In a larger study including a series of 107 testicular tumors, we have recently demonstrated that NIS is expressed in the plasma membrane of the large majority of seminomas and embryonal carcinomas of human testis, while it is absent in Leydig cell cancers [75]. Our data also demonstrated a significant association of the expression of NIS protein with lymphovascular invasion, a well-known marker of aggressiveness. We believe that the association between NIS expression in the tumor cells and lymphovascular invasion may reflect the different biological aggressiveness of testis tumors, suggesting the presence of NIS as an unfavorable prognostic factor. Also, its presence in the plasma membrane compartment of the tumor cells suggests that it may serve as potential carrier of radioiodine for an ablative treatment of cancer tissue.

\section{NIS-based gene therapy}

A successful prostate cancer xenograft model has been first described that accumulates $25-30 \% \mathrm{ID} / \mathrm{g}$ in the tumors [77]. For comparison, poorly differentiated thyroid cancer xenografts accumulated only 4.9-9.3\% ID/g and were not effectively treatable with radioiodine [78]. A NIS gene delivered with an adenovirus vector and a tissue-specific gene promoter, the prostate-specific antigen gene (PSA) promoter, conferred efficient functional NIS expression in prostate cancer xenografts $[79,80]$. In a recent report, Trujillo and coworkers, by using a prostate tumor-specific CRAd in a xenograft model of prostate cancer, demonstrated that the efficacy of radioiodide therapy depends mainly on an efficient viral tumor spread and a decrease in the rate of the efflux of radioisotope [81]. To achieve 
Table 3 Stimulators of iodide uptake in breast cancer cell lines

\begin{tabular}{|c|c|c|c|c|}
\hline Cell line & Stimulator & Mechanism of action & $I^{-}$uptake (fold of induction) & References \\
\hline MCF7 & tRA,9-cis RA & RAR/RXR agonist & $10 \sim 13$ & {$[68]$} \\
\hline MCF7 & AGN190168 & RAR $/ Y$ agonist & $10 \sim 13$ & {$[52]$} \\
\hline MCF7 & Am80 & RARa/ $\beta$ agonist & $\sim 7$ & [56] \\
\hline MCF7 & Theophylline & PDE antagonist/P2R inhibitor & $\sim 4.7$ & [69] \\
\hline MCF7 & LBH589 & HDAC inhibitor & $\sim 2.3$ & [67] \\
\hline T47D & LBH589 & HDAC inhibitor & $\sim 4.8$ & [67] \\
\hline MDA-MB231 & LBH589 & HDAC inhibitor & $\sim 2.7$ & [67] \\
\hline MCF7 & Insulin & Insulin receptor & $\sim 12$ & [66] \\
\hline MCF7 & IGF-I & IGF-I receptor & $\sim 7.8$ & [66] \\
\hline MCF7 & |GF-II & |GF-I| receptor & $\sim 10.3$ & [66] \\
\hline MCF7 & Prolactin & Cytosolic PKs activation & $\sim 9$ & [66] \\
\hline MCF7 & Forskolin & Adenilyl-cyclase/PKA activation & $\sim 3.1$ & {$[66]$} \\
\hline MCF7 & TPA & PKC activation & $\sim 2.6$ & [66] \\
\hline MCF7 & (Bu)2-cAMP & PKA activation & $\sim 3.4$ & [66] \\
\hline
\end{tabular}

Abbreviations: $t R A$ trans retinoic acid, $R A R$ retinoic acid receptor, $P D E$ phosphodiesterase, $H D A C$ histone deacetylase, IGF insulin growth factor, $P K$ protein kinase.

Table 4 NIS expression in extrathyroidal cancer tissues

\begin{tabular}{|c|c|c|c|c|}
\hline $\begin{array}{l}\text { Primary } \\
\text { cancer }\end{array}$ & $\begin{array}{c}\text { No of } \\
\text { specimens }\end{array}$ & $\begin{array}{l}\text { NIS } \\
\text { mRNA }\end{array}$ & $\begin{array}{l}\text { NIS protein } \\
\text { positive (\%) }\end{array}$ & References \\
\hline Bladder & 24 & n.d. & 42 & [13] \\
\hline Cervix & 11 & n.d. & 100 & [13] \\
\hline Colon & 75 & n.d. & 63 & [13] \\
\hline \multirow[t]{2}{*}{ Esophagus } & 15 & n.d. & 47 & [13] \\
\hline & 20 & n.d. & 20 & [13] \\
\hline \multirow[t]{2}{*}{ Liver } & 26 & + & 8 & [74] \\
\hline & $20^{*}$ & + & 100 & [74] \\
\hline Lung & 58 & n.d. & 66 & [13] \\
\hline Ovary & 37 & n.d. & 73 & [13] \\
\hline Pancreas & 11 & n.d. & 64 & [13] \\
\hline Prostate & 34 & n.d. & 74 & {$[13]$} \\
\hline Skin squamous & 18 & n.d. & 56 & [13] \\
\hline \multirow[t]{2}{*}{ Stomach } & 27 & n.d. & 59 & [13] \\
\hline & 4 & + & n.d. & {$[12]$} \\
\hline Submandibular gland & 3 & + & n.d. & [12] \\
\hline \multirow[t]{2}{*}{ Testis } & 11 & n.d. & 9 & [13] \\
\hline & 107 & + & 64 & {$[75]$} \\
\hline Uterus endometrium & 25 & n.d. & 56 & {$[13]$} \\
\hline \multicolumn{5}{|l|}{ Metastatic cancer } \\
\hline Liver** & 15 & n.d. & 80 & {$[76]$} \\
\hline Brain*** & 28 & n.d. & 84 & [40] \\
\hline
\end{tabular}

n.d.: not determined; ${ }^{*}$ cholangiocarcinoma; ${ }^{* *}$ metastasis from breast, pancreas, colorectal and biliary cancers; ${ }^{* * *}$ metastasis from breast cancer. synergistic or additive cytotoxic effects, combined treatments with NIS gene therapy and a tumor targeting strategy, such as utilization of an oncolytic vector [82], are also under experimentation.

\section{Induction of endogenous NIS}

Induction of NIS expression has been obtained in vitro in two testicular cancer cell lines. Findings from our laboratories revealed that NIS expression may be enhanced in vitro in a human embryonal testicular carcinoma cell line by the histone deacetylase inhibitor (HDACi) [75]. Histone acetylation is a known epigenetic mechanism of regulation of gene expression, and its alteration has been reported in many human cancers [83]. In many cell lines of thyroid and non-thyroid cancer, HDACi have been successfully tested to induce radioiodine uptake due to increased NIS expression [84-86]. The same result was obtained in the NTERA cells in our study, showing that, at least in vitro, embryonal testicular tumor cell susceptibility to radioiodine administration may occur, and suggesting the possibility of using radioiodine after pharmacological induction of NIS expression even in this rare tumor histotype. It is noteworthy that these drugs are being tested in clinical trials at doses compatible with those effective in vitro.

Recently, Maggisano et al. analyzed the effects of the HDACi suberoylanilide hydroxamic acid (SAHA) and valproic acid (VPA) on NIS expression and function in rat Leydig testicular carcinoma cells (LC540) [87]. LC540 cells were exposed to SAHA $3 \mu \mathrm{M}$ and VPA $3 \mathrm{mM}$ (alone and in combination), and NIS mRNA and protein levels were evaluated by using, respectively, real-time RT-PCR and western blotting. Also, NIS function was analyzed by iodide uptake assay. They found that both HDACi, used alone, were able to stimulate the transcription of NIS gene, 
but not its protein expression, while the association of SAHA and VPA increased both NIS transcript and protein levels, resulting in a significant enhancement of radioiodine uptake capacity of LC540 cells. These data demonstrate the presence of an epigenetic control of NIS expression in Leydig tumor cells, suggesting the possibility of using the combination of these two $\mathrm{HDACi}$ for a radioiodine-based treatment of these malignancies.

Considering altogether data obtained in breast, prostate and testicular cancer, an important difference seems to emerge. In fact, in testicular and prostate cancer NIS expression, evaluated by immunohistochemistry, appears to be related to the degree of dedifferentiation and aggressiveness [70,75,76]. However, such a relationship is not present in breast cancer [37]. Such a difference seems not due to different methodologies in detecting NIS expression. In fact, the lack of correlation between NIS expression and dedifferentiation was detected in breast tumors both by using RT-PCR and immunohistochemistry [37]. Thus, discrepancy observed between testicular/prostate tumors and breast tumors would depend on the difference of originating tissues. It would be relevant to test such a possibility in a single study, in which testicular, prostate and breast cancer are investigated by the same methodology.

\section{NIS and other malignancies}

Tumors arising in different non-thyroidal organs, such as esophagus, colon, liver, pancreas, lung, ovary, and skin, showed NIS expression (Table 4), though the transporter was mainly and weakly detected only in the cytoplasm of neoplastic cells. Thus, the possibility of using radioiodide treatment in these tumors is strictly dependent on the possibility of achieving an adequate amount of NIS expression in the plasma membrane of tumor cells through stimulation of endogenous or exogenous NIS. According to the recent study of Lacoste et al. [76] (see above), the attribution to the intracellular NIS fraction of a role in tumor cell locomotion may have important implications for those tumors expressing NIS in the cytoplasmic compartment, allowing use as a biomarker of aggressiveness. However, this hypothesis is essentially based on results from only one experimental study and needs to be confirmed by other studies.

Independent of the detection or not in human tumor tissues, a NIS gene therapy approach has been tested in in vitro and in vivo experimental models of many types of neoplasia. As reported in Table 5, various vectors and many different tumor-specific promoters have been used to drive the tissue-specific expression of the NIS gene. Several replication-defective adenoviruses and negativesense single-stranded RNA viruses that avoid their integration into the host genomes have been utilized, and specific promoters, as the hepatocarcinoma-intestine-pancreas gene (HIP), the human telomerase reverse transcriptase (hTERT)
Table 5 NIS gene therapy in extrathyroidal neoplasia

\begin{tabular}{|c|c|c|c|c|}
\hline Neoplasia & Vector & $\begin{array}{l}\text { Combined } \\
\text { treatments }\left({ }^{*}\right)\end{array}$ & $\begin{array}{c}\text { Promoter } \\
\left({ }^{* *}\right)\end{array}$ & References \\
\hline Neuroblastoma & $\begin{array}{l}\text { Plasmid- } \\
\text { polyplex }\end{array}$ & & CMV & {$[88]$} \\
\hline Medulloblastoma & MV & + & & [89] \\
\hline \multirow{2}{*}{ Glioma } & $\mathrm{Ad}$ & & CMV & [90] \\
\hline & Retrovirus & & LTR & [91] \\
\hline \multirow{2}{*}{ Multiple myeloma } & MV & + & & [92] \\
\hline & VSV & + & & [93] \\
\hline Melanoma & $\mathrm{Ad}$ & & TR/TERT & {$[44]$} \\
\hline \multirow[t]{4}{*}{ Mesothelioma } & MV & + & & [94] \\
\hline & $\mathrm{Ad}$ & & CMV & [95] \\
\hline & $\mathrm{Ad}$ & & CMV/CEA & [96] \\
\hline & Lentivirus & & $\mathrm{UbC}$ & {$[97]$} \\
\hline \multirow{4}{*}{$\begin{array}{l}\text { Colon } \\
\text { cancer }\end{array}$} & Lentivirus & + & $\mathrm{UbC}$ & [98] \\
\hline & $\mathrm{Ad}$ & + & CMV & [99] \\
\hline & $\mathrm{Ad}$ & & TERT, TR & {$[44]$} \\
\hline & MV & + & & {$[100]$} \\
\hline \multirow[t]{3}{*}{$\begin{array}{l}\text { Colorectal } \\
\text { cancer }\end{array}$} & $\mathrm{Ad}$ & + & $\begin{array}{l}\text { Wnt- } \\
\text { responsive } \\
\text { TCF4 }\end{array}$ & [101] \\
\hline & $\mathrm{Ad}$ & + & TR & [102] \\
\hline & $\mathrm{Ad}$ & & HIP & [103] \\
\hline \multirow{7}{*}{ Hepatoma } & Plasmid & & AFP & [104] \\
\hline & Retrovirus & + & CMV & {$[105]$} \\
\hline & Retrovirus & + & TERT & {$[106]$} \\
\hline & $\begin{array}{l}\text { Plasmid- } \\
\text { polyplex }\end{array}$ & & CMV & [107] \\
\hline & NIS-MSC & & $\begin{array}{l}\text { CMV in } \\
\text { MSC }\end{array}$ & [108] \\
\hline & $\begin{array}{l}\text { PAMAM- } \\
\text { Ad }\end{array}$ & & CMV & [109] \\
\hline & $\mathrm{Ad}$ & & MUC1 & [110] \\
\hline \multirow{3}{*}{$\begin{array}{l}\text { Pancreatic } \\
\text { cancer }\end{array}$} & MV & + & & [111] \\
\hline & $\mathrm{Ad}$ & + & E3 & {$[82]$} \\
\hline & $\mathrm{Ad}$ & & Survivin & {$[112]$} \\
\hline $\begin{array}{l}\text { Cervical } \\
\text { cancer }\end{array}$ & Retrovirus & + & CMV & [105] \\
\hline
\end{tabular}

$\left({ }^{*}\right)$ : to enhance the tumor growth inhibition; $\left(^{* *}\right)$ : tumor cells-specific promoter. Abbreviations: polyplex synthetic polymeric vector, CMV cytomegalovirus, MV measles virus, Ad adenovirus, LTR long terminal repeat, VSV vesicular stomatitis virus, TR telomerase RNA, TERT telomerase reverse transcriptase, CEA carcinoembryonic antigen, $U b C$ ubiquitin C, Wnt Wingless-related integration site, TCF4 transcription factor 4, PAMAM-Ad adenoviral vectors after coating with synthetic poly(amidoamine) dendrimers, HIP hepatocarcinoma-intestine-pancreas gene, AFP alpha-fetoprotein, MSC mesenchymal stem cells, MUC1 mucin1 gene, E3 E3 antigen.

and the alpha-fetoprotein (AFP) promoters, have shown the capacity to promote NIS expression and iodide uptake in infected cancer cells of various origins [9]. The promising results obtained in such experimental models may open 
the way to making targeted radiotherapy feasible for these types of extrathyroidal cancers.

Currently, at variance with breast and testis cancer cells, there are only few data of stimulation of endogenous NIS expression in other tumor cells. Very recently, Guerrieri and collaborators [113] reported that in liver cancer cells the NIS gene is a direct target of the p53 family, suggesting that its modulation can be exploited to obtain NIS upregulation in vivo.

\section{Biological and technical limitations of NIS-based therapy in extrathyroidal tumors}

For the efficacy of the NIS-based treatment of extrathyroidal malignancies, some fundamental concepts, which still represent major limitations, need to be taken into consideration: the efficacy of the treatment is strictly dependent on the biological half-life of the radioiodide in the body and its retention in the target tumors. Indeed, about $20 \%$ of the injected radioiodide dose must be concentrated for a sufficient time to obtain a complete destruction of the tumor mass [7]. Moreover, while in normal thyrocytes a prolonged iodide retention is assured by incorporation of the trapped iodide into thyroglobulin, in most thyroid cancer this process is less effective, resulting in a higher amount of discharge from tumor tissue [7]. Moreover, except for few tissues provided with a peroxidase activity (i.e. lactoperoxidase in mammary gland), non-thyroid cells do not possess the iodination machinery in their transcriptome. Thus, a prerequisite for the possibility of success of a NIS-based strategy in extrathyroidal tumors is to obtain an adequate amount of NIS protein expression in tumor cell plasma membranes. On this issue, lessons from research in thyroid cancer are highly informative: after a long period of discouraging results of this approach in the clinical trials, the success of radioiodine treatment by NISrecovered expression obtained by using a novel proteinkinase inhibitor has been recently described [114] (see next section).

\section{Review and Conclusions}

Radioiodine administration after TSH stimulation of iodide uptake is a validated treatment effective in most differentiated thyroid cancer. Its success may be likely attributed to the TSH-induced increase of NIS expression and function in the plasma membrane of thyroid cancer cells. Moreover, novel therapeutic approaches targeting the molecular pathways responsible for the loss of differentiation (and subsequent reduction of NIS) are showing promising results in those radioiodide-refractory cancers [115].

These finding justify the efforts to set up a similar strategy, radioiodine-based treatment after stimulation of NIS expression, as a reasonable approach for those extrathyroidal tumors in which NIS can be induced in the membrane of neoplastic cells. Such a therapy would present the advantage of short duration of treatment, reducing the frequency and severity of the eventual side effects.

Introduction of exogenous NIS into non-thyroidal cancer have demonstrated efficient tumor shrinkage by ${ }^{131} \mathrm{I}$ in several in vivo studies [116]. The major improvement of NIS gene-based therapy strategy has come from the use of vectors of oncolytic viruses or replication-defective adenoviruses, thus preventing unfavorable genomic integration. Even non-viral vectors have been efficiently tested for the same purpose (see Table 5).

Also, the use of promoter-specific driving of NIS in the target tissue has been adopted in xenograft models of many tumors. After the successful test of the first construct containing the PSA promoter used to confer efficient functional NIS expression in prostate cancer xenografts [77], several other tumor-specific promoters have shown the capacity to drive NIS expression in specific tumor tissue and determine the radioiodide inhibition of tumor growth in animal experimental models. Finally, synergistic and/or additive cytotoxic effects have been achieved combining treatments with NIS gene therapy and other tumor targeting strategies [9]. An unresolved question is the real feasibility of the application of such a strategy on human patients.

In addition, endogenous NIS stimulation also appears to be a promising approach. It may take advantage of the enormous progress obtained in thyroid cancer field of research in the elucidation of the molecular mechanism that controls thyrocyte differentiation and, in particular, NIS expression. For example, inhibitors of signal transduction pathways, as PI3K/AKT inhibitors and MEK/ERK inhibitors, or HDAC inhibitors, have demonstrated the ability to enhance the functional NIS expression in some thyroid cancer, as well as non-thyroid cancer cells $[85,117,118]$ and, very recently, a clinical pilot study has actually demonstrated the effectiveness of the MEK inhibitor selumetinib to increase radioiodide uptake in a number of patients with advanced thyroid cancer [114].

Isoform-specific signal transduction pathways are probably involved in the tissue-specific regulation of NIS expression. Thus, elucidation of the molecular mechanism underlying such regulatory pathways may contribute to achieving a further enhancement of functional NIS expression in extrathyroidal cancer tissues, expanding the application of radioiodide therapy to all NIS-expressing neoplasia.

\section{Abbreviations}

AFP: Alpha-fetoprotein; BC: Breast cancer; CMV: Cytomegalovirus; CRAd: Conditionally replicating adenovirus; ER: Estrogen receptor;

HDAC: Histone deacetylase; HDACi: Histone deacetylase inhibitor; HER2: Human epidermal growth factor receptor 2; HIP: Hepatocarcinoma-intestine-pancreas gene; hTERT: Human telomerase reverse transcriptase; hTR: Human telomerase subunits RNA; IGF: Insulin growth factor; ${ }^{131}$ I: Radioiodide-131; MUC-1: Mucin 1; NIS: Sodium iodide symporter; PI3K: Phosphoinositide 3-kinase; 
PPARY: Peroxisome proliferator-activated receptor $\gamma$; PR: Progesterone receptor; PSA: Prostate-specific antigen gene; RA: Retinoic acid; RARa: Retinoic acid receptor-alpha; RT-PCR: Reverse transcriptase polymerase chain reaction; SAHA: Suberoylanilide hydroxamic; TNBC: Triple-negative BCs; TPO: Thyroid peroxidase; TSH: Thyroid stimulating hormone; VPA: Valproic acid.

\section{Competing interests}

The authors declare that they have no competing interests.

\section{Authors' contributions}

SM and DR contributed to the conception of the idea, drafted the manuscript and critically reviewed the final manuscript; DR and SB elaborated the sections 3, 4, 7, the figure and the tables and editing the manuscript; CP, GD and MN elaborated the section 5; AT and GB elaborated the section 6; SF elaborated the sections 1 and 2 and conclusions. All authors read and approved the final manuscript.

\section{Acknowledgements}

We thank Paul Casella for editorial feedback on the manuscript. This work was supported by Fondazione Umberto Di Mario ONLUS and was supported by the Associazione Italiana per la Ricerca sul Cancro (AIRC) (grant $n^{\circ}$ IG 10296).

\section{Author details}

'Department of Urology, University of Modena and Reggio Emilia, Via Largo del Pozzo, 71, Modena 41100, Italy. ${ }^{2}$ Department of Health Sciences, University of Catanzaro 'Magna Graecia', Catanzaro 88100, Italy. ${ }^{3}$ Department of Medical and Biological Sciences, University of Udine, Udine 33100, Italy. ${ }^{4}$ Department of Drug Sciences and Products for Health, University of Messina, Messina 98100, Italy. ${ }^{5}$ Department of Internal Medicine and Medical Specialties, University of Rome 'Sapienza', Rome 00100, Italy.

Received: 17 November 2013 Accepted: 17 April 2014 Published: 30 April 2014

\section{References}

1. Dai G, Levy O, Carrasco N: Cloning and characterization of the thyroid iodide transporter. Nature 1996, 379:458-460.

2. Smanik PA, Ryu KY, Theil KS, Mazzaferri EL, Jhiang SM: Expression, exon-intron organization, and chromosome mapping of the human sodium iodide symporter. Endocrinology 1997, 138:3555-3558.

3. Dohan O, De la Vieja A, Paroder V, Riedel C, Artani M, Reed M, Ginter CS, Carrasco N: The sodium/iodide symporter (NIS): characterization, regulation, and medical significance. Endocr Rev 2003, 24:48-77.

4. Riedel C, Levy O, Carrasco N: Post-transcriptional regulation of the sodium/iodide symporter by thyrotropin. J Biol Chem 2001, 276:21458-21463.

5. Kogai T, Taki K, Brent GA: Enhancement of sodium/iodide symporter expression in thyroid and breast cancer. Endocr Relat Cancer 2006, 13:797-826.

6. Arturi F, Russo D, Giuffrida D, Schlumberger M, Filetti S: Sodium-iodide symporter (NIS) gene expression in lymph node metastases of papillary thyroid carcinomas. Eur J Endocrinol 2000, 143:623-627.

7. Schlumberger M, Lacroix L, Russo D, Filetti S, Bidart JM: Defects in iodide metabolism in thyroid cancer and implications for the follow-up and treatment of patients. Nat Clin Pract Endocrinol Metab 2007, 3:260-269.

8. Wartofsky L, Van Nostrand D: Radioiodine treatment of well-differentiated thyroid cancer. Endocrine 2012, 42(3):506-513.

9. Kogai T, Brent GA: The sodium iodide symporter (NIS): regulation and approaches to targeting for cancer therapeutics. Pharmacol Therapeutics 2012, 135:355-370.

10. Russo D, Damante G, Puxeddu E, Durante C, Filetti S: Epigenetics of thyroid cancer and novel therapeutic targets. J Mol Endocrinol 2011, 46(3):R73-81.

11. Smith VE, Sharma N, Watkins RJ, Read ML, Ryan GA, Kwan PP, Martin A, Watkinson JC, Boelaert K, Franklyn JA, McCabe CJ: Manipulation of PBF/ PTTG1IP phosphorylation status; a potential new therapeutic strategy for improving radioiodine uptake in thyroid and other tumors. J Clin Endocrinol Metab 2013, 98(7):2876-2886.

12. Bruno R, Giannasio P, Ronga G, Baudin E, Travagli JP, Russo D, Filetti S, Schlumberger M: Sodium iodide symporter expression and radioiodine distribution in extrathyroidal tissues. J Endocrinol Invest 2004, 27(11):1010-1014.
13. Wapnir IL, van de Rijn M, Nowels K, Amenta PS, Walton K, Montgomery K, Greco RS, Dohán O, Carrasco N: Immunohistochemical profile of the sodium/iodide symporter in thyroid, breast, and other carcinomas using high density tissue microarrays and conventional sections. J Clin Endocrinol Metab 2003, 88(4):1880-1888

14. Wolff J: Transport of iodide and other anions in the thyroid gland. Physiol Rev 1964, 44:45-90.

15. Wright EM: Active transport of iodide and other anions across the choroid plexus. J Physiol 1974, 240:535-566.

16. Portulano C, Paroder-Belenitsky M, Carrasco N: The Na+/l- symporter (NIS): mechanism and medical impact. Endocr Rev 2014, 35(1):106-149.

17. Spitzweg C, Joba W, Schriever K, Goellner JR, Morris JC, Heufelder AE: Analysis of human sodium iodide symporter immunoreactivity in human exocrine glands. J Clin Endocrinol Metab 1999, 84(11):4178-4184.

18. Vayre L, Sabourin JC, Caillou B, Ducreux M, Schlumberger M, Bidart JM Immunohistochemical analysis of $\mathrm{Na}+/ \mathrm{l}-$ symporter distribution in human extra-thyroidal tissues. Eur J Endocrinol 1999, 141:382-386.

19. Altorjay A, Dohan O, Szilagyi A, Paroder M, Wapnir IL, Carrasco N: Expression of the $\mathrm{Na}+/ \mathrm{l}-$ symporter (NIS) is markedly decreased or absent in gastric cancer and intestinal metaplastic mucosa of Barrett esophagus. BMC Cancer 2007, 7:5.

20. La Perle KM, Kim DC, Hall NC, Bobbey A, Shen DH, Nagy RS, Wakely PE Jr, Lehman A, Jarjoura D, Jhiang SM: Modulation of sodium/iodide symporter expression in the salivary gland. Thyroid 2013, 23(8):1029-1036.

21. Russo D, Scipioni A, Durante C, Ferretti E, Gandini L, Maggisano V, Paoli D, Verrienti A, Costante G, Lenzi A, Filetti S: Expression and localization of the sodium/iodide symporter (NIS) in testicular cells. Endocrine 2011, 40(1):35-40.

22. Bidart JM, Lacroix L, Evain-Brion D, Caillou B, Lazar V, Frydman R, Bellet D, Filetti S, Schlumberger M: Expression of $\mathrm{Na}+/ \mathrm{l}-$ symporter and pendred syndrome genes in trophoblast cells. J Clin Endocrinol Metab 2000, 85(11):4367-4372.

23. Tazebay UH, Wapnir IL, Levy O, Dohan O, Zuckier LS, Zhao QH, Deng HF Amenta PS, Fineberg S, Pestell RG, Carrasco N: The mammary gland iodide transporter is expressed during lactation and in breast cancer. Nat Med 2000, 6:871-878

24. Brown-Grant K: Extrathyroidal iodide concentrating mechanisms. Physiol Rev 1961, 41:189-213.

25. Nicola JP, Basquin C, Portulano C, Reyna-Neyra A, Paroder M, Carrasco N: The $\mathrm{Na}+/ \mathrm{l}-$ symporter mediates active iodide uptake in the intestine. Am J Physiol Cell Physiol 2009, 296:C654-C662.

26. Josefsson M, Grunditz T, Ohlsson T, Ekblad E: Sodium/iodide-symporter: distribution in different mammals and role in entero-thyroid circulation of iodide. Acta Physio/ Scand 2002, 175:129-137.

27. Semba RD, Delange F: lodine in human milk: perspectives for infant health. Nutr Rev 2001, 59:269-278.

28. Cho JY, Leveille R, Kao R, Rousset B, Parlow AF, Burak WEJ, Mazzaferri EL, Jhiang SM: Hormonal regulation of radioiodide uptake activity and $\mathrm{Na}+/ \mathrm{l}-$ symporter expression in mammary glands. J Clin Endocrinol Metab 2000, 85:2936.

29. Ronga G, Bruno R, Puxeddu E, Calcinaro F, Montesano T, Tralascio L, Colandrea M, Durante C, Maranghi M, Filetti S, Russo D: Radioiodine uptake in non-lactating mammary glands: evidence for a causative role of hyperprolactinemia. Thyroid 2007, 17:363-366.

30. Wapnir IL, Goris M, Yudd A, Dohan O, Adelman D, Nowels K, Carrasco N: The $\mathrm{Na}+/ \mathrm{l}-$ symporter mediates iodide uptake in breast cancer metastases and can be selectively down-regulated in the thyroid. Clin Cancer Res 2004, 10(13):4294-4302.

31. Rudnicka L, Sińczak A, Szybiński P, Huszno B, Stachura J: Expression of the $\mathrm{Na}(+) / \mathrm{I}(-)$ symporter in invasive ductal breast cancer. Folia Histochem Cytobiol 2003, 41(1):37-40.

32. Tandon A, Shrivastava A, Kumar A, Prayaga AK, Sundaram C, Godbole MM: Sodium iodide symporter, estrogen receptor, and progesterone receptor expression in carcinoma breast-an immunohistochemical analysis. Indian J Pathol Microbiol 2011, 54(4):745-751.

33. Peyrottes I, Navarro V, Ondo-Mendez A, Marcellin D, Bellanger L, Marsault R, Lindenthal S, Ettore F, Darcourt J, Pourcher T: Immunoanalysis indicates that the sodium iodide symporter is not overexpressed in intracellular compartments in thyroid and breast cancers. Eur J Endocrinol 2009, 160(2):215-225.

34. Beyer SJ, Zhang X, Jimenez RE, Lee ML, Richardson AL, Huang K, Jhiang SM: Microarray analysis of genes associated with cell surface NIS protein levels in breast cancer. BMC Res Notes 2011, 11(4):397. 
35. Upadhyay G, Singh R, Agarwal G, Mishra SK, Pal L, Pradhan PK, Das BK, Godbole MM: Functional expression of sodium iodide symporter (NIS) in human breast cancer tissue. Breast Cancer Res Treat 2003, 77(2):157-165.

36. Renier C, Yao C, Goris M, Ghosh M, Katznelson L, Nowles K, Gambhir SS, Wapnir I: Endogenous NIS expression in triple-negative breast cancers. Ann Surg Oncol 2009, 16(4):962-968.

37. Ryan J, Curran CE, Hennessy E, Newell J, Morris JC, Kerin MJ, Dwyer RM: The sodium iodide symporter (NIS) and potential regulators in normal, benign and malignant human breast tissue. PLOS One 2011, 6(1):e16023.

38. Foulkes WD, Smith IE, Reis-Filho JS: Triple-negative breast cancer. N Engl J Med 2010, 363:1938-1948.

39. Andreetta C, Minisini AM, Miscoria M, Puglisi F: First-line chemotherapy with or without biologic agents for metastatic breast cancer. Crit Rev Oncol Hematol 2010, 76(2):99-111.

40. Renier C, Vogel H, Offor O, Yao C, Wapnir I: Breast cancer brain metastases express the sodium iodide symporter. J Neurooncol 2010, 96(3):331-336.

41. Damle AA, Narkar AA, Badwe RA: Radioiodide uptake and sodium iodide symporter expression in breast carcinoma. Indian J Exp Biol 2011, 49(6):416-422.

42. Oh HJ, Chung JK, Kang JH, Kang WJ, Noh DY, Park IA, Jeong JM, Lee DS, Lee MC: The relationship between expression of the sodium/iodide symporter gene and the status of hormonal receptors in human breast cancer tissue. Cancer Res Treat 2005, 37(4):247-250.

43. Montiel-Equihua CA, Martín-Duque P, de la Vieja A, Quintanilla M, Burnet J, Vassaux G, Lemoine NR: Targeting sodium/iodide symporter gene expression for estrogen-regulated imaging and therapy in breast cancer. Cancer Gene Ther 2008, 15(7):465-473.

44. Riesco-Eizaguirre G, De la Vieja A, Rodríguez I, Miranda S, Martín-Duque P, Vassaux G, Santisteban P: Telomerase-driven expression of the sodium iodide symporter (NIS) for in vivo radioiodide treatment of cancer: a new broad-spectrum NIS-mediated antitumor approach. J Clin Endocrinol Metab 2011, 96(9):E1435-1443.

45. Kim NW, Piatyszek MA, Prowse KR, Harley CB, West MD, Ho PL, Coviello GM, Wright WE, Weinrich SL, Shay JW: Specific association of human telomerase activity with immortal cells and cancer. Science 1994, 266:2011-2015.

46. Shay JW, Bacchetti SA: Survey of telomerase activity in human cancer. Eur J Cancer 1997, 33:787-791.

47. Keith WN, Jeffry Evans TR, Glasspool RM: Telomerase and cancer: time to move from a promising target to a clinical reality. J Pathol 2001, 195:404-414.

48. Trujillo MA, Oneal MJ, Davydova J, Bergert E, Yamamoto M, Morris JC 3rd: Construction of an MUC-1 promoter driven, conditionally replicating adenovirus that expresses the sodium iodide symporter for gene therapy of breast cancer. Breast Cancer Res 2009, 11(4):R53.

49. Gendler SJ: MUC1, the renaissance molecule. J Mammary Gland Biol Neoplasia 2001, 6:339-353.

50. Lim SJ, Paeng JC, Kim SJ, Kim SY, Lee H, Moon DH: Enhanced expression of adenovirus-mediated sodium iodide symporter gene in MCF-7 breast cancer cells with retinoic acid treatment. J Nucl Med 2007, 48(3):398-404.

51. Angulo A, Suto C, Heyman RA, Ghazal P: Characterization of the sequences of the human cytomegalovirus enhancer that mediate differential regulation by natural and synthetic retinoids. Mol Endocrinol 1996, 10:781-793.

52. Kogai T, Kanamoto Y, Li Al, Che LH, Ohashi E, Taki K, Chandraratna RA, Saito T, Brent GA: Differential regulation of sodium/iodide symporter gene expression by nuclear receptor ligands in MCF-7 breast cancer cells. Endocrinology 2005, 146:3059-3069.

53. Alotaibi H, Yaman E, Salvatore D, Di Dato V, Telkoparan P, Di Lauro R, Tazebay UH: Intronic elements in the Na+/l- symporter gene (NIS) interact with retinoic acid receptors and mediate initiation of transcription. Nucleic Acids Res 2010, 38:3172-3185

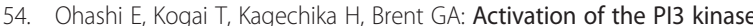
pathway by retinoic acid mediates sodium/iodide symporter induction and iodide transport in MCF-7 breast cancer cells. Cancer Res 2009, 69:3443-3450

55. Kogai T, Liu YY, Richter LL, Mody K, Kagechika H, Brent GA: Regulation of sodium iodide symporter gene expression by Rac1/p38 $\beta$ mitogenactivated protein kinase signaling pathway in MCF-7 breast cancer cells. J Biol Chem 2012, 287(5):3292-3300.

56. Kogai T, Kanamoto Y, Che LH, Taki K, Moatamed F, Schultz JJ, Brent GA: Systemic retinoic acid treatment induces sodium/iodide symporter expression and radioiodide uptake in mouse breast cancer models. Cancer Res 2004, 64(1):415-422

57. Cheong SJ, Jang D, Jeong HJ, Lim ST, Sohn MH, Katznellenbogen JA, Kim DW: Reduction of stimulated sodium iodide symporter expression by estrogen receptor ligands in breast cancer cells. Nucl Med Biol 2011, 38(2):287-294.

58. Levy O, De la Vieja A, Ginter CS, Riedel C, Dai G, Carrasco N: N-linked glycosylation of the thyroid Na+/l- symporter (NIS). Implications for its secondary structure model. J Biol Chem 1998, 273:22657-22663.

59. Seibert K, Shafie SM, Triche TJ, Whang-Peng JJ, O'Brien SJ, Toney JH, Huff KK, Lippman ME: Clonal variation of MCF-7 breast cancer cells in vitro and in athymic nude mice. Cancer Res 1983, 43(5):2223-2239.

60. Knostman KA, McCubrey JA, Morrison CD, Zhang Z, Capen CC, Jhiang SM: PI3K activation is associated with intracellular sodium/iodide symporter protein expression in breast cancer. BMC Cancer 2007, 7:137.

61. Dohan O, De la Vieja A, Carrasco N: Hydrocortisone and purinergic signaling stimulate sodium/iodide symporter (NIS)-mediated iodide transport in breast cancer cells. Mol Endocrinol 2006, 20:1121-1137.

62. Unterholzner S, Willhauck MJ, Cengic N, Schutz M, Goke B, Morris JC, Spitzweg C: Dexamethasone stimulation of retinoic acid-induced sodium iodide symporter expression and cytotoxicity of 131-I in breast cancer cells. J Clin Endocrinol Metab 2006, 91:69-78.

63. Sponziello M, Scipioni A, Durante C, Verrienti A, Maranghi M, Giacomelli L, Ferretti E, Celano M, Filetti S, Russo D: Regulation of sodium/iodide symporter and lactoperoxidase expression in four human breast cancer cell lines. J Endocrinol Invest 2010, 33:2-6.

64. Willhauck MJ, Kane DJ O, Wunderlich N, Goke B, Spitzweg C: Stimulation of retinoic acid-induced functional sodium iodide symporter (NIS) expression and cytotoxicity of (1)(3)(1)! by carbamazepine in breast cancer cells. Breast Cancer Res Treat 2011, 125:377-386.

65. Willhauck MJ, Sharif-Samani B, Senekowitsch-Schmidtke R, Wunderlich N, Goke B, Morris JC, Spitzweg C: Functional sodium iodide symporter expression in breast cancer xenografts in vivo after systemic treatment with retinoic acid and dexamethasone. Breast Cancer Res Treat 2008, 109:263-272.

66. Arturi F, Ferretti E, Presta I, Mattei T, Scipioni A, Scarpelli D, Bruno R, Lacroix L, Tosi E, Gulino A, Russo D, Filetti S: Regulation of iodide uptake and sodium/iodide symporter expression in the MCF-7 human breast cancer cell line. J Clin Endocrinol Metab 2005, 90:2321-2326.

67. Fortunati N, Catalano MG, Marano F, Mugoni V, Pugliese M, Bosco O, Mainini F, Boccuzzi G: The pan-DAC inhibitor LBH589 is a multi-functional agent in breast cancer cells: cytotoxic drug and inducer of sodium-iodide symporter (NIS). Breast Cancer Res Treat 2010, 124(3):667-675

68. Kogai T, Schultz JJ, Johnson LS, Huang M, Brent GA: Retinoic acid induces sodium/iodide symporter gene expression and radioiodide uptake in the MCF-7 breast cancer cell line. Proc Natl Acad Sci U S A 2000, 97(15):8519-8524.

69. Yoon JK, Park BN, Paik JY, Jung KH, Ko BH, Lee KH: Effects of theophylline on radioiodide uptake in MCF-7 breast cancer and NIS gene transduced SNU-C5 colon cancer cells. Cancer Biother Radiopharm 2009, 24:201-208.

70. Navarra M, Micali S, Lepore S, Cesinaro AM, Celano M, De Sighinolfi MC, Gaetani C, Filetti S, Bianchi G, Russo D: Expression of the sodium/iodide symporter in human prostate adenocarcinoma. Urology 2010, 75:773-778.

71. Huang D, Casale GP, Tian J, Wehbi NK, Abrahams NA, Kaleem Z, Smith LM, Johansson SL, Elkahwaji JE: Hemstreet GP3rd: quantitative fluorescence imaging analysis for cancer biomarker discover application to beta-catenin in archived prostate specimens. Cancer Epidemiol Biomarkers Prev 2007, 16:1371-1381.

72. Trouttet-Masson S, Selmi-Ruby S, Bernier-Valentin F, Porra V, Berger-Dutrieux N, Decaussin M, Peix JL, Perrin A, Bournaud C, Orgiazzi J, Borson-Chazot F, Franc B, Rousset $B$ : Evidence for transcriptional and posttranscriptional alterations of the sodium/iodide symporter expression in hypofunctioning benign and malignant thyroid tumors. Am J Pathol 2004, 165:25-34.

73. Sodrè AK, Rubio IG, Galrão AL, Knobel M, Tomimori EK, Alves VA, Kanamura CT, Buchpiguel CA, Watanabe T, Friguglietti CU, Kulcsar MA, Medeiros-Neto G, Camargo RY: Association of low sodium iodide symporter messenger ribonucleic acid expression in malignant thyroid nodules with increased intracellular protein staining. J Clin Endocrinol Metab 2008, 93:4141-4145.

74. Liu B, Hervé J, Bioulac-Sage P, Valogne Y, Roux J, Yilmaz F, Boisgard R, Guettier C, Calès P, Tavitian B, Samuel D, Clerc J, Bréchot C, Faivre J: Sodium iodide symporter is expressed at the preneoplastic stages of liver carcinogenesis and in human cholangiocarcinoma. Gastroenterology 2007, 132(4):1495-1503. 
75. Micali S, Maggisano V, Cesinaro A, Celano M, Territo A, Reggiani Bonetti L, Sponziello M, Migaldi M, Navarra M, Bianchi G, Filetti S, Russo D: Sodium/ iodide symporter is expressed in the majority of seminomas and embryonal testicular carcinomas. J Endocrinol 2013, 216:125-133.

76. Lacoste C, Hervé J, Bou Nader M, Dos Santos A, Moniaux N, Valogne Y, Montjean R, Dorseuil O, Samuel D, Cassio D, Portulano C, Carrasco N, Bréchot C, Faivre J: lodide transporter NIS regulates cancer cell motility and invasiveness by interacting with the Rho guanine nucleotide exchange factor LARG. Cancer Res 2012, 72(21):5505-5515.

77. Spitzweg C, Dietz AB, O'Connor MK, Bergert ER, Tindall DJ, Young CY, Morris JC: In vivo sodium iodide symporter gene therapy of prostate cancer. Gene Ther 2001, 8:1524-1531.

78. Shimura H, Haraguchi K, Miyazaki A, Endo T, Onaya T: lodide uptake and experimental 1311 therapy in transplanted undifferentiated thyroid cancer cells expressing the $\mathrm{Na}+/ /-$ symporter gene. Endocrinology 1997 , 138:4493-4496.

79. Spitzweg C, O'Connor MK, Bergert ER, Tindall DJ, Young CY, Morris JC Treatment of prostate cancer by radioiodine therapy after tissue-specific expression of the sodium iodide symporter. Cancer Res 2000, 60:6526-6530

80. Dwyer RM, Schatz SM, Bergert ER, Myers RM, Harvey ME, Classic KL, Blanco MC, Frisk CS, Marler RJ, Davis BJ, O'Connor MK, Russell SJ, Morris JC: A preclinical large animal model of adenovirus-mediated expression of the sodium-iodide symporter for radioiodide imaging and therapy of locally recurrent prostate cancer. Mol Ther 2005, 12:835-841.

81. Trujillo MA, Oneal MJ, McDonough SJ, Morris JC: Viral dose, radioiodide uptake, and delayed efflux in adenovirus-mediated NIS radiovirotherapy correlates with treatment efficacy. Gene Ther 2013, 20:567-574.

82. Hakkarainen T, Rajecki M, Sarparanta M, Tenhunen M, Airaksinen AJ, Desmond RA, Kairemo K, Hemminki A: Targeted radiotherapy for prostate cancer with an oncolytic adenovirus coding for human sodium iodide symporter. Clin Cancer Res 2009, 15:5396-5403.

83. Chi $P$, Allis CD, Wang GG: Covalent histone modifications-miswritten, misinterpreted and mis-erased in human cancers. Nat Rev Cancer 2010, 10:457-459.

84. Puppin C, D'Aurizio F, D'Elia AV, Cesaratto L, Tell G, Russo D, Filetti S, Ferretti E, Tosi E, Mattei T, Pianta A, Pellizzari L, Damante G: Effects of histone acetylation on NIS promoter and expression of thyroid-specific transcription factors. Endocrinology 2005, 146:3967-3974

85. Liu Z, Xing M: Induction of sodium/iodide symporter (NIS) expression and radioiodine uptake in non-thyroid cancer cells. PLOS ONE 2012, 7:e31729.

86. Russo D, Durante C, Bulotta S, Puppin C, Puxeddu E, Filetti S, Damante G: Targeting histone deacetylase in thyroid cancer. Expert Opin Ther Target 2013, 17:179-193.

87. Maggisano V, Puppin C, Celano M, D’Agostino M, Sponziello M, Micali S, Navarra M, Damante G, Filetti S, Russo D: Cooperation of histone deacetylase inhibitors SAHA and valproic acid in promoting sodium/ iodide symporter expression and function in rat Leydig testicular carcinoma cells. Endocrine 2014, 45(1):148-152.

88. Klutz K, Russ V, Willhauck MJ, Wunderlich N, Zach C, Gildehaus FJ, Göke B, Wagner E, Ogris M, Spitzweg C: Targeted radioiodine therapy of neuroblastoma tumors following systemic nonviral delivery of the sodium iodide symporter gene. Clin Cancer Res 2009, 15(19):6079-6086.

89. Hutzen B, Pierson CR, Russell SJ, Galanis E, Raffel C, Studebaker AW: Treatment of medulloblastoma using an oncolytic measles virus encoding the thyroidal sodium iodide symporter shows enhanced efficacy with radioiodine. BMC Cancer 2012, 12:508.

90. Cho JY, Xing S, Liu X, Buckwalter TL, Hwa L, Sferra TJ, Chiu IM, Jhiang SM: Expression and activity of human $\mathrm{Na}+/ \mathrm{l}-$ symporter in human glioma cells by adenovirus-mediated gene delivery. Gene Ther 2000, 7(9):740-749.

91. Shen DH, Marsee DK, Schaap J, Yang W, Cho JY, Hinkle G, Nagaraja HN, Kloos RT, Barth RF, Jhiang SM: Effects of dose, intervention time, and radionuclide on sodium iodide symporter (NIS)-targeted radionuclide therapy. Gene Ther 2004, 11(2):161-169.

92. Dingli D, Peng KW, Harvey ME, Greipp PR, O'Connor MK, Cattaneo R, Morris JC, Russell SJ: Image-guided radiovirotherapy for multiple myeloma using a recombinant measles virus expressing the thyroidal sodium iodide symporter. Blood 2004, 103:1641-1646.

93. Goel A, Carlson SK, Classic KL, Greiner S, Naik S, Power AT, Bell JC, Russell SJ: Radioiodide imaging and radiovirotherapy of multiple myeloma using
VSV(Delta51)-NIS, an attenuated vesicular stomatitis virus encoding the sodium iodide symporter gene. Blood 2007, 110:2342-2350.

94. Li H, Peng KW, Dingli D, Kratzke RA, Russell SJ: Oncolytic measles viruses encoding interferon beta and the thyroidal sodium iodide symporter gene for mesothelioma virotherapy. Cancer Gene Ther 2010, 17(8):550-558.

95. Boland A, Ricard M, Opolon P, Bidart JM, Yeh P, Filetti S, Schlumberger M, Perricaudet M: Adenovirus-mediated transfer of the thyroid sodium/ iodide symporter gene into tumors for a targeted radiotherapy. Cancer Res 2000, 60(13):3484-3492.

96. Scholz IV, Cengic N, Baker CH, Harrington KJ, Maletz K, Bergert ER, Vile R, Göke B, Morris JC, Spitzweg C: Radioiodine therapy of colon cancer following tissue-specific sodium iodide symporter gene transfer. Gene Ther 2005, 12(3):272-280.

97. Kim HJ, Jeon YH, Kang JH, Lee YJ, Kim Kl, Chung HK, Jeong JM, Lee DS, Lee $M C$, Chung JK: In vivo long-term imaging and radioiodine therapy by sodium-iodide symporter gene expression using a lentiviral system containing ubiquitin C promoter. Cancer Biol Ther 2007, 6(7):1130-1135.

98. Jeon YH, Choi Y, Kim HJ, Kim CW, Jeong JM, Lee DS, Chung JK: Human sodium iodide symporter gene adjunctive radiotherapy to enhance the preventive effect of hMUC1 DNA vaccine. Int J Cancer 2007 121:1593-1599.

99. Ahn SJ, Jeon YH, Lee YJ, Lee YL, Lee SW, Ahn BC, Ha JH, Lee J: Enhanced anti-tumor effects of combined MDR1 RNA interference and human sodium/iodide symporter (NIS) radioiodine gene therapy using an adenoviral system in a colon cancer model. Cancer Gene Ther 2010, 17:492-500.

100. Inubushi M, Jin YN, Murai C, Hata H, Kitagawa Y, Saga T: Single-photonemission computed tomography of spontaneous liver metastasis from orthotopically implanted human colon cancer cell line stably expressing human sodium/iodide symporter reporter gene. EJNMMI Res 2012, 2(1):46.

101. Peerlinck I, Merron A, Baril P, Conchon S, Martin-Duque P, Hindorf C, Burnet J, Quintanilla M, Hingorani M, lggo R, Lemoine NR, Harrington K, Vassaux G: Targeted radionuclide therapy using a Wnt-targeted replicating adenovirus encoding the $\mathrm{Na} / \mathrm{I}$ symporter. Clin Cancer Res 2009, 15:6595-6601.

102. Hingorani M, White $C L$, Zaidi S, Pandha HS, Melcher AA, Bhide SA, Nutting CM, Syrigos KN, Vile RG, Vassaux G, Harrington KJ: Therapeutic effect of sodium iodide symporter gene therapy combined with external beam radiotherapy and targeted drugs that inhibit DNA repair. Mol Ther 2010, 18:1599-1605.

103. Hervé J, Cunha AS, Liu B, Valogne Y, Longuet M, Boisgard R, Brégerie O, Roux J, Guettier C, Calès P, Tavitian B, Samuel D, Clerc J, Bréchot C, Faivre J: Internal radiotherapy of liver cancer with rat hepatocarcinomaintestine-pancreas gene as a liver tumor-specific promoter. Hum Gene Ther 2008, 19:915-926.

104. Willhauck MJ, Sharif Samani BR, Klutz K, Cengic N, Wolf I, Mohr L, Geissler M, Senekowitsch-Schmidtke R, Göke B, Morris JC, Spitzweg C: Alpha-fetoprotein promoter-targeted sodium iodide symporter gene therapy of hepatocellular carcinoma. Gene Ther 2008, 15:214-223.

105. Jeon $Y H$, Lee $H W$, Lee $Y L$, Kim JE, Hwang MH, Jeong SY, Lee SW, Ahn BC, Ha JH, Lee J: Combined E7-dendritic cell-based immunotherapy and human sodium/iodide symporter radioiodine gene therapy with monitoring of antitumor effects by bioluminescent imaging in a mouse model of uterine cervical cancer. Cancer Biother Radiopharm 2011, 26:671-679.

106. Kim S, Youn H, Song MG, Kang JH, Chung HK, Lee DS, Chung JK: Complementary treatment of siTERT for improving the antitumor effect of TERT-specific I-131 therapy. Cancer Gene Ther 2012, 19:263-270.

107. Klutz K, Willhauck MJ, Dohmen C, Wunderlich N, Knoop K, Zach C, Senekowitsch-Schmidtke R, Gildehaus FJ, Ziegler S, Fürst S, Göke B, Wagner E, Ogris M, Spitzweg C: Image-guided tumor-selective radioiodine therapy of liver cancer after systemic nonviral delivery of the sodium iodide symporter gene. Hum Gene Ther 2011, 22:1563-1574.

108. Knoop K, Kolokythas M, Klutz K, Willhauck MJ, Wunderlich N, Draganovici D, Zach C, Gildehaus FJ, Böning G, Göke B, Wagner E, Nelson PJ, Spitzweg C: Image-guided, tumor stroma-targeted 1311 therapy of hepatocellular cancer after systemic mesenchymal stem cell-mediated NIS gene delivery. Mol Ther 2011, 19:1704-1713.

109. Grünwald GK, Vetter A, Klutz K, Willhauck MJ, Schwenk N, SenekowitschSchmidtke R, Schwaiger M, Zach C, Wagner E, Göke B, Holm PS, Ogris M, Spitzweg C: Systemic image-guided liver cancer radiovirotherapy using dendrimer-coated adenovirus encoding the sodium iodide symporter as theranostic gene. J Nucl Med 2013, 54:1450-1457. 
110. Dwyer RM, Bergert ER, O'Connor MK, Gendler SJ, Morris JC: Adenovirus-mediated and targeted expression of the sodium-iodide symporter permits in vivo radioiodide imaging and therapy of pancreatic tumors. Hum Gene Ther 2006, 17:661-668.

111. Carlson SK, Classic KL, Hadac EM, Dingli D, Bender CE, Kemp BJ, Russell SJ: Quantitative molecular imaging of viral therapy for pancreatic cancer using an engineered measles virus expressing the sodium-iodide symporter reporter gene. AJR Am J Roentgenol 2009, 192:279-287.

112. Huang R, Zhao Z, Ma X, Li S, Gong R, Kuang A: Targeting of tumor radioiodine therapy by expression of the sodium iodide symporter under control of the survivin promoter. Cancer Gene Ther 2011, 18:144-152.

113. Guerrieri F, Piconese S, Lacoste C, Schinzari V, Testoni B, Valogne $Y$, Gerbal-Chaloin S, Samuel D, Bréchot C, Faivre J, Levrero M: The sodium/iodide symporter NIS is a transcriptional target of the p53-family members in liver cancer cells. Cell Death Dis 2013, 19(4):e807.

114. Ho AL, Grewal RK, Leboeuf R, Sherman E, Pfister DG, Deandreis D, Pentlow KS, Zanzonico PB, Haque S, Gavane S, Ghossein RA, Ricarte-Filho JC, Domínquez JM, Shen R, Tuttle RM, Larson SM, Fagin J: Selumetinib-enhanced radioiodine uptake in advanced thyroid cancer. N Engl J Med 2013, 368(7):623-632.

115. Xing $M$, Haugen BR, Schlumberger M: Progress in molecular-based management of differentiated thyroid cancer. Lancet 2013, 381(9871):1058-1069.

116. Hingorani M, Spitzweg C, Vassaux G, Newbold K, Melcher A, Pandha H, Vile R, Harrington $\mathrm{K}$ : The biology of the sodium iodide symporter and its potential for targeted gene delivery. Curr Cancer Drug Targets 2010, 10:242-267.

117. Kogai T, Sajid-Crockett S, Newmarch LS, Liu YY, Brent GA: Phosphoinositide-3-kinase inhibition induces sodium/iodide symporter expression in rat thyroid cells and human papillary thyroid cancer cells. J Endocrinol 2008, 199:243-252.

118. Jung KH, Paik JY, Ko BH, Lee KH: Mitogen-activated protein kinase signaling enhances sodium iodide symporter function and efficacy of radioiodide therapy in nonthyroidal cancer cells. J Nucl Med 2008, 49:1966-1972.

\section{doi:10.1186/1471-2407-14-303}

Cite this article as: Micali et al:: Sodium iodide symporter (NIS) in extrathyroidal malignancies: focus on breast and urological cancer. $B M C$ Cancer 2014 14:303.

\section{Submit your next manuscript to BioMed Central and take full advantage of:}

- Convenient online submission

- Thorough peer review

- No space constraints or color figure charges

- Immediate publication on acceptance

- Inclusion in PubMed, CAS, Scopus and Google Scholar

- Research which is freely available for redistribution 